\title{
Nucleic Acid Homologies in the Genus Pseudomonas
}

\author{
N. J. PALlERONI,' R. KUNISAWA, R. CONTOPOULOU, and M. DOUDOROFF \\ Department of Bacteriology and Immunology, University of California, Berkeley, California 94720
}

\begin{abstract}
On the basis of ribosomal ribonucleic acid homologies, the genus Pseudomonas can be divided into at least five distinct groups, some of which are as distantly related to each other as they are to Escherichia coli. One of these groups contains members of the genus Xanthomonas. The data presented support and extend the previous grouping based on deoxyribonucleic acid homologies and support the current view that the portion of the genome coding for ribosomal ribonucleic acid is more conserved in the course of evolution than the bulk of the genome.
\end{abstract}

For about nine years our laboratory has been largely involved in taxonomic studies of the genus Pseudomonas. Our first approach was the phenotypic characterization of a large number of strains using mainly nutritional characters. On the basis of phenotypic resemblance, we recognized several "species groups," comprised of what we regarded as recognizable species. Below the specific rank, we further recognized a number of "biotypes," some of which had been previously described as species, and many of which may deserve specific rank (14). Deoxyribonucleic acid (DNA)-DNA hybridization experiments generally supported our conclusions based on phenotypic data but showed that some of the species and biotypes were quite heterogeneous with respect to DNA homology. It was also found that some species groups were sufficiently closely related to each other to be united in a larger DNA homology complex. For example, the "P. fluorescens complex" was found to contain not only the "fluorescent group" but also the nonfluorescent pseudomonads that had been assigned to the "alcaligenes" and "stutzeri" groups (10, 14). Our studies have been reviewed recently (9).

To pursue further our studies on bacterial phylogeny and speciation, we have resorted to ribosomal ribonucleic acid (rRNA)-DNA hybridizations among selected members of the various DNA homology groups, and included three species of Xanthomonas in the studies. The results are reported in the present paper.

\footnotetext{
${ }^{1}$ Present address: Research Division, Hoffmann-La Roche, Inc., Nutley, N.J. 07110.
}

(This paper was presented at The Annual Meeting of the American Society for Microbiology, 1973.)

\section{MATERIALS AND METHODS}

Bacterial strains. The bacterial strains used in the presently described experiments are numbered as in our previous publications $(1,2,4,7,8,10-12,14)$. Where applicable, the American Type Culture Collection (ATCC) number has been included. Pseudomonas viridiflava VIRID 1 (NCPPB 1249) and Xanthomonas campestris XC-1 were received from D. C. Hildebrand, Department of Plant Pathology, University of California, Berkeley, and Xanthomonas pruni XP-218 and Xanthomonas translucens XT-122 were sent by M. P. Starr, Department of Bacteriology, University of California, Davis.

Preparation of rRNA. For the preparation of unlabeled rRNA, most strains were grown in a medium containing $0.033 \mathrm{M} \mathrm{K}-\mathrm{Na}$ phosphate buffer, $\mathrm{pH} 6.8$; $\left(\mathrm{NH}_{4}\right)_{2} \mathrm{SO}_{4}, 0.1 \%$; asparagine, $0.2 \%$; yeast extract, $0.5 \%$; Hutner mineral base (3), $10 \mathrm{ml}$ per liter. For the growth of $P$. maltophilia, DL-sodium lactate was substituted for asparagine. $P$. saccharophila was grown in a medium containing $0.033 \mathrm{M} \mathrm{K}-\mathrm{Na}$ phosphate buffer, $\mathrm{pH} 6.8 ; \mathrm{NH}_{4} \mathrm{Cl}, 0.1 \% ; \mathrm{MgSO}_{4} \cdot 7 \mathrm{H}_{2} \mathrm{O}, 0.05 \%$; ferric ammonium citrate, $0.005 \% ; \mathrm{CaCl}_{2}, 0.0005 \%$; and sodium succinate, $0.2 \%$. For the growth of $P$. diminuta, the same basal medium was used as for $P$. saccharophila except that succinate was replaced by asparagine and the essential growth factors (1) were added. The cultures were grown at $30 \mathrm{C}$ on a rotary shaker. The cells were suspended in $0.02 \mathrm{M}$ tris(hydroxymethyl)aminomethane (Tris)-hydrochloride buffer, $\mathrm{pH} 7.4$, containing $0.01 \mathrm{M} \mathrm{MgCl}_{2}$. Cell concentrations ranging from 10 to $20 \%$ (wet weight/ vol) were used. DNase was added to the suspension to a final concentration of $10 \mu \mathrm{g} / \mathrm{ml}$. The suspension was 
passed through a French pressure cell at 12,000 psi. All the above operations were carried out in the cold. For most rRNA extractions the procedure was as follows. The extract was centrifuged for $15 \mathrm{~min}$ at $27,000 \times g$, the pellet was discarded, and the supernatant fluid was centrifuged for $45 \mathrm{~min}$ at $127,000 \times g$ or $75 \mathrm{~min}$ at $88,700 \times \mathrm{g}$. The ribosome pellet was suspended in about 0.25 of the original volume of $0.05 \mathrm{M}$ phosphate buffer, $\mathrm{pH} 6.8$, containing $0.1 \mathrm{M} \mathrm{NaCl}$, and the suspension was extracted three times using each time one volume of liquefied phenol saturated with $0.5 \%$ sodium dodecyl sulfate in $0.02 \mathrm{M}$ phosphate buffer, $\mathrm{pH} 6.8$, containing $0.1 \mathrm{M}$ $\mathrm{NaCl}$. The extractions were performed at room temperature, and every time the phases were separated by centrifugation in a refrigerated centrifuge. The final aqueous phase was treated 5 to 10 times with several volumes of anhydrous ethyl ether to remove the dissolved phenol, and the RNA was precipitated with two volumes of $95 \%$ ethanol.

Some variations of the above method were used for the extraction of the rRNA from bacteria that gave unsatisfactory preparations. For the extraction of $P$. maltophilia and of $P$. aeruginos $a$, bentonite was added to the ribosome suspension in an amount equivalent to half the estimated RNA content (wt/wt). In addition, fresh bentonite was added to the aqueous phase with each phenol extraction. In the extraction of $P$. delafieldii, the French-press extract was allowed to stand for $10 \mathrm{~min}$ at room temperature (to promote DNase reaction) before bentonite was added. For the preparation of Escherichia coli rRNA, the Frenchpress extract was received directly into buffer-saturated phenol containing bentonite.

All RNA preparations were stored in $70 \%$ ( $\mathrm{vol} / \mathrm{vol}$ ) ethanol at $-10 \mathrm{C}$. The RNA was centrifuged and resuspended in $0.1 \times \mathrm{SSC}(1 \times \mathrm{SSC}$ is $0.15 \mathrm{M} \mathrm{NaCl}$ and $0.015 \mathrm{M}$ trisodium citrate in water adjusted to $\mathrm{pH}$ 7.0 with $\mathrm{HCl}$ ) before use in competition experiments. Samples of all RNA preparations were checked by sucrose-gradient centrifugation ( 2 to $20 \%$ sucrose in 1 $\times \mathrm{SSC}$ ) for $16 \mathrm{~h}$ at $53,000 \times g$. The bulk RNA was used as competitor RNA without further fractionation.

Labeled RNA was prepared from bacteria grown either in ${ }^{3} \mathrm{H}$-uridine or ${ }^{32} \mathrm{P}$-ortho-phosphate-containing media. ${ }^{3} \mathrm{H}$-labeled uridine $\left(9 \times 10^{-7} \mathrm{M}, 28 \mathrm{Ci}\right.$ per mmol) was added to media containing phosphate buffer $(0.033 \mathrm{M}, \mathrm{pH} 6.8)$; $\left(\mathrm{NH}_{4}\right)_{2} \mathrm{SO}_{4}, 0.1 \%$; Hutner mineral base (3), $10 \mathrm{ml}$ per liter; (Difco) vitamin-free Casamino Acids, $0.2 \%$; and DL-asparagine, $0.2 \%$ for $P$. fluorescens, or DL-lactate, $0.2 \%$ for $P$. aeruginos $a$ and $P$. maltophilia. For the labeling of $X$. campestris the composition of the medium was: phosphate buffer (0.033 M, pH 6.8); $\mathrm{NH}_{4} \mathrm{Cl}, 0.1 \% ; \mathrm{MgSO}_{4} \cdot 7 \mathrm{H}_{2} \mathrm{O}$, $0.05 \%$; ferric-ammonium citrate, $0.005 \% ; \mathrm{CaCl}_{2}$, $0.0005 \%$; and Casamino Acids, $0.5 \%$.

Those strains that did not take up uridine were labeled with ${ }^{32} \mathrm{P}$ ( $2.5 \mathrm{mCi}$ of carrier-free phosphate per $100 \mathrm{ml}$ of medium). The medium used for $P$. cepacia, $P$. acidovorans, and $P$. delafieldii contained Tris-hydrochloride buffer $(0.01 \mathrm{M}, \mathrm{pH} 7.4) ; \mathrm{KH}_{2} \mathrm{PO}_{4}$, $0.0025 \% ; \mathrm{NH}_{4} \mathrm{Cl}, 0.1 \%$; ferric-ammonium citrate,
$0.005 \% ; \mathrm{CaCl}_{2}, 0.0005 \%$; Casamino Acids, $0.2 \%$; and DL-lactate, $0.2 \%$. To this medium, growth factors (1) were added for the growth of $P$. diminuta.

The cells were harvested when the culture reached a density equivalent to 150 to $175 \mathrm{Klett}$ units (red filter no. 66). The rRNA was extracted by the methods described above, and after sucrose-gradient fractionation, the peaks corresponding to the $23 S$ and $16 S$ RNA were pooled and used as reference RNA. For the hybridization experiments, the DNA was immobilized on nitrocellulose membranes $10 \mathrm{~mm}$ in diameter (Schleicher and Schuell, type B-6); each filter had an average of $20 \mu \mathrm{g}$ of DNA. Hybridizations were carried out at $65 \mathrm{C}$ for $8 \mathrm{~h}$ in vials containing $1 \mu \mathrm{g}$ of labeled reference RNA and $100 \mu \mathrm{g}$ of bulk competitor RNA in a final volume of $0.25 \mathrm{ml}$ of $2 \times$ SSC. Control vials with labeled RNA and no competitor RNA were also included. After hybridization, the filters were washed once with $2 \times \mathrm{SSC}$ at $65 \mathrm{C}$ and placed individually in vials with $0.2 \mathrm{ml}$ of $2 \times$ SSC containing $25 \mu \mathrm{g}$ of pancreatic RNase and 1,500 U (about $4 \mu \mathrm{g}$ ) of $T_{1}$ RNase per $\mathrm{ml}$. The vials were incubated for $1 \mathrm{~h}$ at 37 $\mathrm{C}$, and the filters were washed twice with $2 \times \mathrm{SSC}$ at $37 \mathrm{C}$, dried, and counted in a scintillation counter. The percentage of competition was calculated as described by Ballard et al. for DNA-DNA competition experiments (2).

DNA homologies. DNA-DNA homologies were taken from our previously published data and were based on DNA-DNA hybridizations performed at $T_{m}-25 \mathrm{C}$ by the competition technique (2).

Phenotypic similarities. Phenotypic matching coefficients $\left(\mathrm{S}_{\mathrm{SM}}\right)$ for 169 characters were calculated as described by Sokal and Sneath (13).

DNA base composition ( $G$ plus $C$ mol percent) was determined by using the buoyant density method of

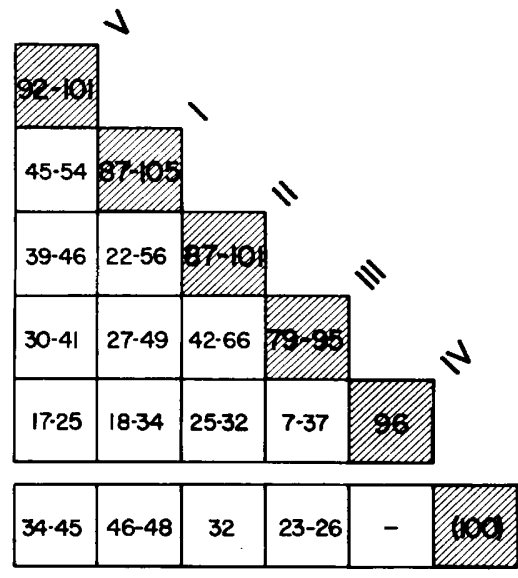

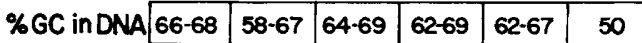

FIG. 1. Ranges of intra- and intergroup $r R N A$ homologies, expressed as percentage of competition in $r R N A-D N A$ hybridizations. The groups are designated by Roman numerals. 
TABLE 1. Nucleic acid homologies of group I

\begin{tabular}{|c|c|c|c|c|c|c|c|}
\hline \multirow{3}{*}{ Strain } & \multirow{3}{*}{$\begin{array}{c}\text { GC in } \\
\text { DNA } \\
(\%)\end{array}$} & \multicolumn{3}{|c|}{ Reference: $P$. aeruginosa } & \multicolumn{3}{|c|}{ Reference: $P$. fluorescens D31 } \\
\hline & & \multirow{2}{*}{$\begin{array}{c}\text { Phenotypic } \\
\text { matching } \\
\text { coefficient } \\
\mathrm{S}_{\mathrm{SM}}\end{array}$} & \multicolumn{2}{|c|}{ Competition (\%) } & \multirow{2}{*}{$\begin{array}{c}\text { Phenotypic } \\
\text { matching } \\
\text { coefficient } \\
\mathrm{S}_{\mathrm{SM}}\end{array}$} & \multicolumn{2}{|c|}{ Competition (\%) } \\
\hline & & & $\begin{array}{l}\text { DNA- } \\
\text { DNA }\end{array}$ & $\begin{array}{l}\text { rRNA- } \\
\text { DNA }\end{array}$ & & $\begin{array}{l}\text { DNA- } \\
\text { DNA }\end{array}$ & $\begin{array}{c}\text { rRNA- } \\
\text { DNA }\end{array}$ \\
\hline $\begin{array}{l}P . \text { aeruginosa } 131,17503^{a} \\
P . \text { fluorescens } \mathrm{D} 31,9447^{a}\end{array}$ & $\begin{array}{l}68 \\
63\end{array}$ & 75 & 28 & 87 & 75 & 28 & 87 \\
\hline $\begin{array}{l}\text { P. fluorescens A } 192 \text {, } \\
13525^{a}\end{array}$ & 60 & 69 & 23 & 93 & 85 & 53 & 102 \\
\hline $\begin{array}{l}\text { P. fluorescens B } 400 \text {, } \\
17815^{\alpha}\end{array}$ & 62 & 69 & $21^{b}$ & $\mathrm{ND}^{c}$ & 80 & 26 & 105 \\
\hline $\begin{array}{l}P . \text { fluorescens C } 18 \text {, } \\
17400^{a}\end{array}$ & 61 & 79 & 24 & 91 & 87 & 46 & 101 \\
\hline $\begin{array}{l}\text { P. fluorescens E 38, } \\
13985^{a}\end{array}$ & 63 & 74 & 17 & ND & 93 & 85 & 101 \\
\hline $\begin{array}{l}\text { P. fluorescens F 83, } \\
12983^{a}\end{array}$ & 59 & 68 & 14 & ND & 79 & 56 & 95 \\
\hline P. putida A $90,12633^{a}$ & 63 & 71 & 13 & 80 & 75 & 43 & 94 \\
\hline P. putida B, 53, 17430 & 60 & 67 & $16^{b}$ & 85 & 77 & 43 & 97 \\
\hline P. cichorii 758 & 58 & 64 & ND & 88 & 74 & 19 & 99 \\
\hline P. syringae 755 & $59^{b}$ & 59 & $0^{b}$ & 92 & 69 & 4 & 97 \\
\hline P. savastanoi 756 & $58^{\circ}$ & 60 & ND & ND & 69 & $7^{b}$ & 102 \\
\hline P. phaseolicola 753 & $58^{b}$ & 54 & 14 & 88 & 64 & 41 & 97 \\
\hline P. mori 765 & ND & 56 & ND & ND & 64 & ND & 96 \\
\hline P. glycinea 767 & $58^{b}$ & 51 & ND & ND & 61 & ND & 101 \\
\hline P. tomato 759 & ND & 56 & 0 & 89 & 67 & 32 & 98 \\
\hline$P$. viridiflava VIRID 1 & ND & 54 & ND & ND & 62 & ND & 97 \\
\hline P. stutzeri $221,17588^{a}$ & 65 & 72 & $10^{b}$ & 96 & 66 & 57 & 94 \\
\hline P. stanieri $224,17591^{a}$ & 62 & 72 & $0^{b}$ & ND & 66 & ND & 93 \\
\hline $\begin{array}{l}P . \text { mendocina } \mathrm{CH} 20 \text {, } \\
25411^{a}\end{array}$ & 62 & 74 & 14 & 95 & 72 & 21 & 88 \\
\hline $\begin{array}{l}\text { P. pseudoalcaligenes } 63 \text {, } \\
17440^{\circ}\end{array}$ & 63 & 70 & 33 & 92 & 67 & 23 & 87 \\
\hline
\end{tabular}

${ }^{a}$ ATCC number.

Value obtained with a related strain.

${ }^{c}$ ND, not done.

TABLE. 2. Nucleic acid homologies of groups $I I$ and IV

\begin{tabular}{|c|c|c|c|c|}
\hline \multirow{2}{*}{ Group } & \multirow{2}{*}{$\begin{array}{l}\text { GC in DNA } \\
(\%)\end{array}$} & \multirow{2}{*}{$\begin{array}{l}\text { Phenotypic } \\
\text { matching } \\
\text { coefficient } \\
\text { S }_{\mathrm{SM}}\end{array}$} & \multicolumn{2}{|c|}{ Competition (\%) } \\
\hline & & & DNA-DNA & rRNA-DNA \\
\hline $\begin{array}{l}\text { Group II Reference: } P \text {. cepacia } 382,17759^{a} \\
\quad P . \text { cepacia } 717,727 \\
P . \text { marginata } 704 \\
P . \text { caryophylli } 721 \\
\text { P. pickettii } \mathrm{K}-288,27511^{\alpha} \\
P \text {. solanacearum } 779\end{array}$ & $\begin{array}{c}68,66 \\
69 \\
66 \\
64 \\
66\end{array}$ & $\begin{array}{c}89,91 \\
79 \\
71 \\
69 \\
56\end{array}$ & $\begin{array}{l}82^{b} \\
35 \\
24 \\
26 \\
0^{c}\end{array}$ & $\begin{array}{r}101 \\
98 \\
97 \\
87 \\
88\end{array}$ \\
\hline $\begin{array}{l}\text { Group IV Reference: } P \text {. diminuta } 501,11568^{a} \\
\quad P \text {. vesicularis } 500,11426^{a}\end{array}$ & 66 & 92 & 27 & 96 \\
\hline
\end{tabular}

${ }^{a}$ ATCC number.

${ }^{b}$ Value obtained with strain 727.

${ }^{c}$ Value obtained with a related strain. 
TABLE 3. Nucleic acid homologies of group III

\begin{tabular}{|c|c|c|c|c|c|c|c|}
\hline \multirow{3}{*}{ Group III } & \multirow{3}{*}{$\begin{array}{c}G+C \\
\text { in DNA } \\
(\%)\end{array}$} & \multicolumn{3}{|c|}{ Reference: $P$. acidovorans 14} & \multicolumn{3}{|c|}{ Reference: $P$. delafieldii 134} \\
\hline & & \multirow{2}{*}{$\begin{array}{l}\text { Phenotypic } \\
\text { matching } \\
\text { coefficient } \\
\mathrm{S}_{\mathrm{SM}}\end{array}$} & \multicolumn{2}{|c|}{ Competition (\%) } & \multirow{2}{*}{$\begin{array}{l}\text { Phenotypic } \\
\text { matching } \\
\text { coefficient } \\
\text { S }_{\mathrm{SM}}\end{array}$} & \multicolumn{2}{|c|}{ Competition (\%) } \\
\hline & & & $\begin{array}{l}\text { DNA- } \\
\text { DNA }\end{array}$ & $\begin{array}{l}\text { rRNA- } \\
\text { DNA }\end{array}$ & & $\begin{array}{l}\text { DNA- } \\
\text { DNA }\end{array}$ & $\begin{array}{l}\text { rRNA- } \\
\text { DNA }\end{array}$ \\
\hline $\begin{array}{l}\text { P. acidovorans } \\
14,15668^{a}\end{array}$ & 67 & & & & 68 & 0 & 83 \\
\hline $\begin{array}{l}\text { P. testosteroni } \\
\quad 78,11996^{\alpha}\end{array}$ & 61 & 85 & 33 & 92 & 70 & 0 & 85 \\
\hline $\begin{array}{l}\text { P. delafieldii } \\
134,17506^{a}\end{array}$ & 65 & 68 & 0 & 89 & & & \\
\hline $\begin{array}{l}\text { P. facilis } 332 \text {, } \\
17695^{a}\end{array}$ & 64 & 63 & $\mathbf{0}$ & 87 & 89 & 100 & 92 \\
\hline $\begin{array}{l}\text { P. saccharophila } \\
15946^{a}\end{array}$ & 69 & 66 & $\mathbf{0}$ & 79 & 76 & 0 & 95 \\
\hline
\end{tabular}

${ }^{a}$ ATCC number.

TABLE 4. RNA homologies of group $V$

\begin{tabular}{|c|c|c|c|}
\hline \multirow{3}{*}{ Group V } & \multirow{3}{*}{$\begin{array}{c}G+C \\
\text { in DNA } \\
(\%)\end{array}$} & \multicolumn{2}{|c|}{$\begin{array}{l}\text { RNA competition } \\
(\%)\end{array}$} \\
\hline & & \multicolumn{2}{|c|}{ Reference } \\
\hline & & $\begin{array}{c}\text { P. malt- } \\
\text { ophilia } 67\end{array}$ & $\begin{array}{c}X . \text { cam- } \\
\text { pestris } \\
\text { XC-1 }\end{array}$ \\
\hline $\begin{array}{l}\text { P. maltophilia } \\
67,13637^{a}\end{array}$ & 67 & & 95 \\
\hline $\begin{array}{l}\text { X. campestris } \\
\mathrm{XC}-1\end{array}$ & $68^{b}$ & 92 & \\
\hline X. pruni XP-218 & $67^{b}$ & 96 & 97 \\
\hline $\begin{array}{c}X \text {. translucens } \\
\mathrm{XT}-122\end{array}$ & $68^{\circ}$ & 93 & 101 \\
\hline
\end{tabular}

a ATCC number.

${ }^{b}$ Value reported for a related strain.

M. Mandel. In a few cases, values were taken from the literature.

\section{RESULTS}

Under the conditions of our experiments, the binding of homologous RNA in the absence of competitor ranged from 1.1 to $1.9 \mu \mathrm{g}$ of immobilized DNA per mg for different species. We do not consider these differences to be significant, particularly in competition experiments, because of good agreement between reciprocal hybridizations. In addition, for technical reasons we have not yet solved the problem of maximal binding of homologous RNA, and therefore no conclusions as to the fraction of the genome coding for rRNA can be drawn from our data.

The RNA hybridization experiments demonstrate that the pseudomonads that we have studied fall into five RNA homology groups. The internal values for each group are considerably higher than those obtained in hybridizations using strains selected from different groups. In fact, members of different groups are as distantly related to each other as they are to $E$. coli (Fig. 1). The figure also shows the overlap in the ranges of $\mathrm{G}$ plus $\mathrm{C}$ content of the DNA of the different groups.

Group I corresponds to the $P$. fluorescens DNA homology complex, and group II to the $P$. pseudomallei-P. cepacia DNA homology complex (9). Group III comprises two DNA homology groups (the $P$. acidovorans and the $P$. facilis- $P$. delafieldii groups) as well as $P$. saccharophila. Group IV corresponds to the $P$. diminuta DNA homology group. Group V contains $P$. maltophilia and members of the genus Xanthomonas.

The intragroup relationships with respect to DNA-DNA and rRNA-DNA homologies using one or two reference strains of each group are shown in Tables 1, 2, 3, and 4. Also included in Tables 1,2, and 3 are the DNA base compositions and matching coefficients for all strains tested. Because the Xanthomonas species have not been analyzed by our methods, no matching coefficients and DNA-DNA homologies are available. That $P$. maltophilia was related by DNA-DNA homology to Xanthomonas to a larger extent than other species was suggested by M. P. Starr and Rita Colwell (personal communications). 
Table 5 gives data on intergroup rRNA-DNA homologies of selected strains of the various groups. These data are summarized in Fig. 1.

\section{DISCUSSION}

It has been previously demonstrated that the segment of bacterial genome coding for rRNA is more conserved in the course of evolution than the bulk of the genome $(5,6)$. This is clearly supported by the relatively higher homologies between rRNA and DNA than between DNA and DNA both in the intragroup and intergroup hybridizations reported in this paper. A striking example is the composition of group III (Table 3 ), which contains species sharing no appreciable DNA-DNA homology.
Were it not for the rRNA-DNA hybridization experiments, we could not have established any relationship among the members contained in this group.

The five groups that we have established on the basis of rRNA homologies seem to be very distantly related to each other phylogenetically. In our opinion, the five RNA homology groups deserve at least independent genus (and possibly family or order) assignment. Although there are certain phenotypic characters studied by us that can be used to differentiate among species within the genus Pseudomonas, we have not been able to find enough useful characters (including DNA base composition) to distinguish all species of any one group from those belonging to other groups, with the possible exception of group IV, which has some special

TABLE 5. Intergroup $r R N A$ homologies

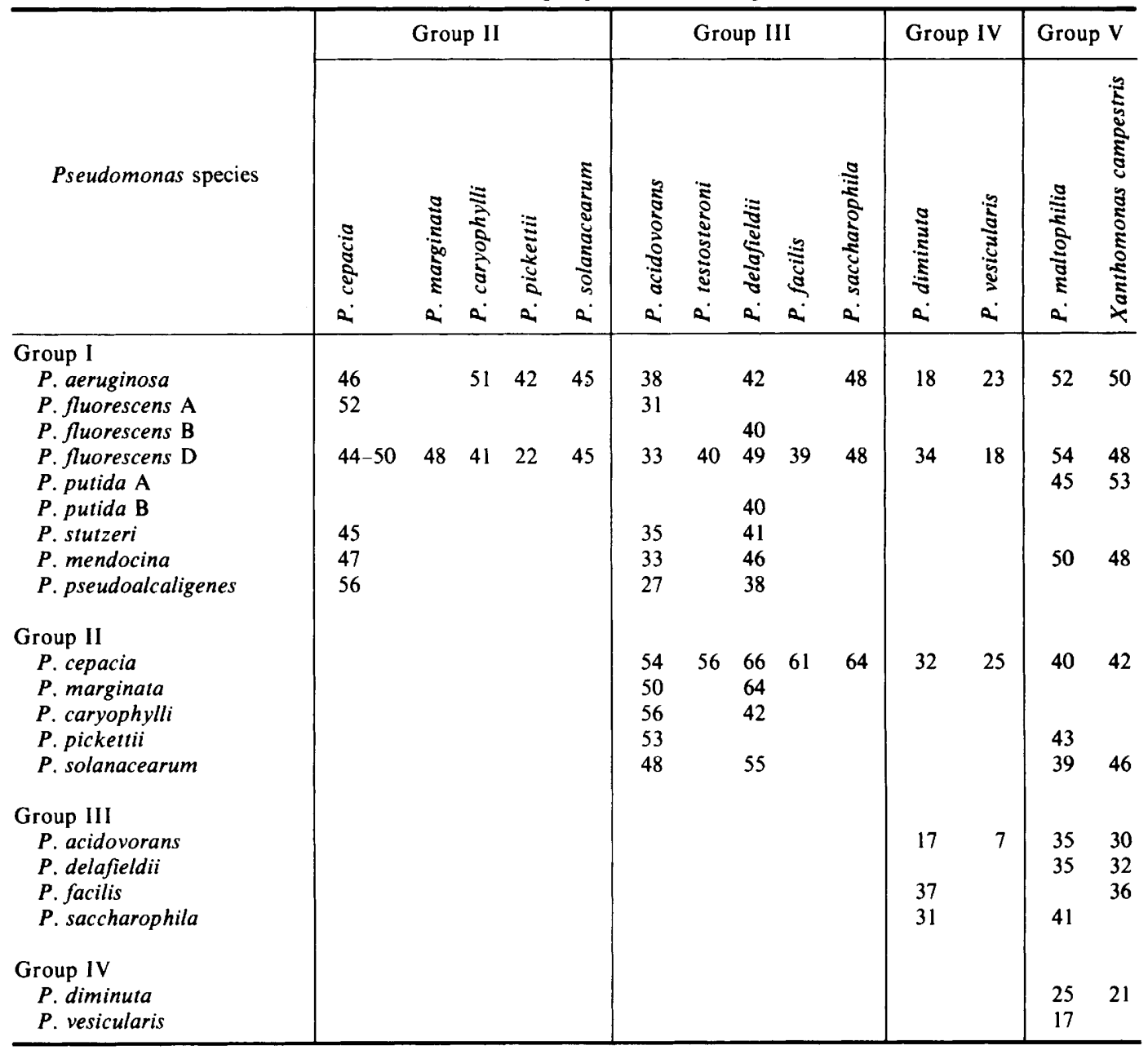




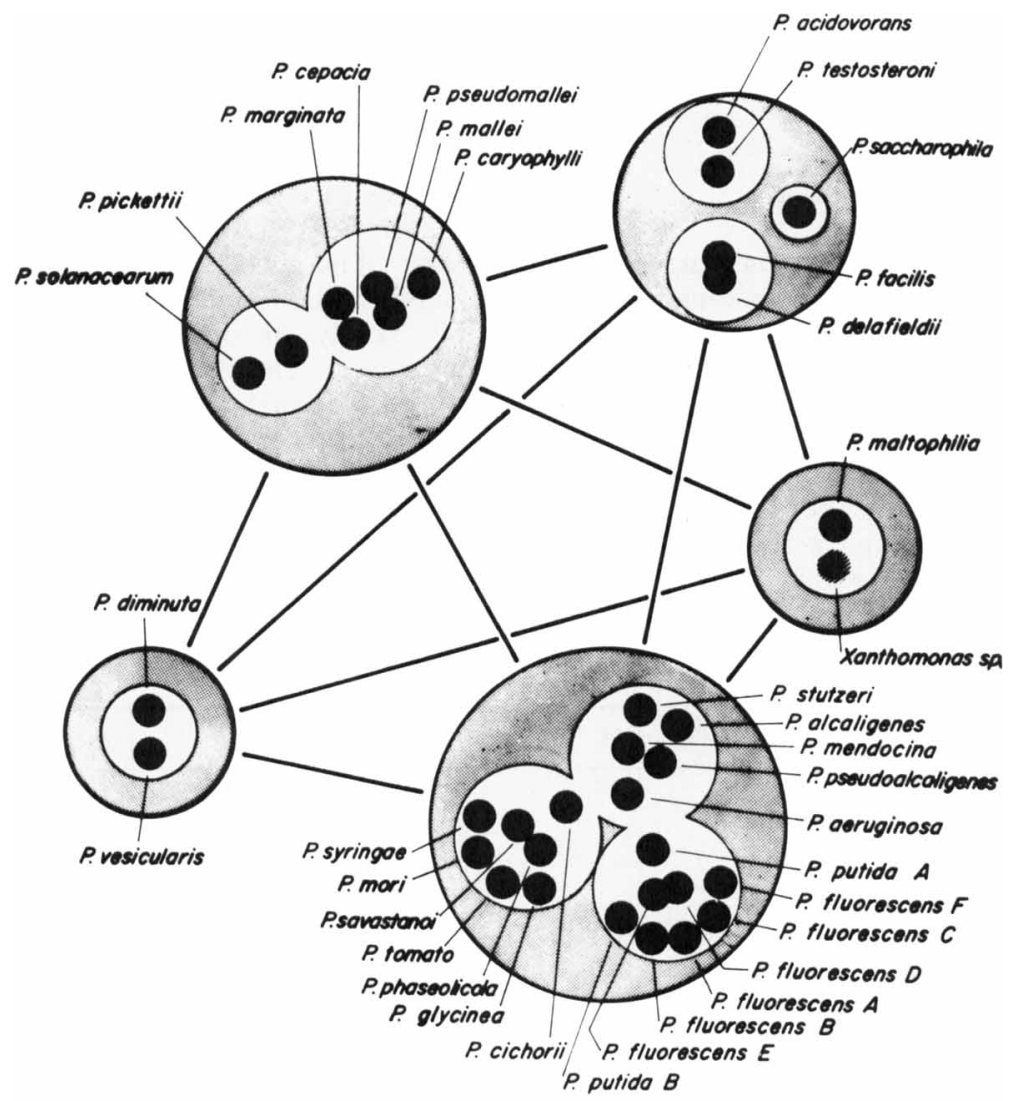

FIG. 2. Pseudomonas species and biotypes arranged according to rRNA and DNA homologies. The shaded circles represent rRNA homology groups.

morphological and physiological properties. Hopefully, better characters will be found in the future to distinguish clearly among the groups.

On the basis of many DNA-DNA hybridization experiments previously reported by us and the rRNA homologies reported here, we may at present visualize the relationships among $P_{s e u}$ domonas species that we have studied as shown in Fig. 2. The relative distances of the five homology groups from each other are shown in the figure as well as we could achieve in a simple two-dimensional graph.

\section{ACKNOWLEDGMENTS}

This investigation was supported by Public Health Service Grant AI-1808 from the National Institute of Allergy and Infectious Diseases.

\section{REPRINT REQUESTS}

Address requests for reprints to: N. J. Palleroni, Research Division, Hoffmann-La Roche, Inc., Nutley, N. J. 07110.

\section{LITERATURE CITED}

1. Ballard, R. W., M. Doudoroff, R. Y. Stanier, and M. Mandel. 1968. Taxonomy of the aerobic pseudomonads: Pseudomonas diminuta and $P$. vesiculare. J. Gen. Microbiol. 53:349-361.

2. Ballard, R. W., N. J. Palleroni, M. Doudoroff, and R. Y. Stanier. 1970. Taxonomy of the aerobic pseudomonads: Pseudomonas cepacia, P. marginata, $P$. alliicola, and $P$. caryophylli. J. Gen. Microbiol. 60:199-214.

3. Cohen-Bazire, G., W. R. Sistrom, and R. Y. Stanier. 1957. Kinetic studies of pigment synthesis by non-sulphur purple bacteria. J. Cell. Comp. Physiol. 49:25-33.

4. Davis, D. H., R. Y. Stanier, M. Doudoroff, and M. Mandel. 1970. Taxonomic studies on some gram negative polarly flagellated "hydrogen bacteria" and related species. Arch. Mikrobiol. 70:1-13.

5. Doi, R. H., and R. T. Igarashi. 1965. Conservation of ribosomal and messenger ribonucleic acid cistrons in Bacillus species. J. Bacteriol. 90:384-390.

6. Dubnau, D., I. Smith, P. Morell, and J. Marmur. 1965. Genetic conservation in Bacillus species and 
nucleic acid homologies. Proc. Nat. Acad. Sci. U.S.A. 54:491498.

7. Palleroni, N. J., R. W. Ballard, E. Ralston, and M. Doudoroff. 1972. Deoxyribonucleic acid homologies among some Pseudomonas species. J. Bacteriol. 110:1-11.

8. Palleroni, N. J., and M. Doudoroff. 1971. Phenotypic characterization and deoxyribonucleic acid homologies of Pseudomonas solanacearum. J. Bacteriol. 107:690-696.

9. Palleroni, N. J., and M. Doudoroff. 1972. Some properties and taxonomic subdivisions of the genus Pseudomonas. Annu. Rev. Phytopathol. 10:73-100.

10. Palleroni, N. J., M. Doudoroff, R. Y. Stanier, R. E. Solanes, and M. Mandel. 1970. Taxonomy of the aerobic pseudomonads: the properties of the
Pseudomonas stutzeri group. J. Gen. Microbiol. 60:215-231.

11. Ralston, E., N. J. Palleroni, and M. Doudoroff. 1972. Deoxyribonucleic acid homologies of some so-called "Hydrogenomonas" species. J. Bacteriol. 109:465-466.

12. Ralston, E., N. J. Palleroni, and M. Doudoroff. 1973. Pseudomonas pickettii, a new species of clinical origin related to Pseudomonas solanacearum. Int. J. Syst. Bacteriol. 23:15-19.

13. Sokal, R. R., and P. H. A. Sneath. 1963. Principles of numerical taxonomy. W. H. Freeman and Co., San Francisco.

14. Stanier, R. Y., N. J. Palleroni, and M. Doudoroff. 1966. The aerobic pseudomonads: a taxonomic study. J. Gen. Microbiol. 43:159-271. 